\title{
OS MARCOS GEOGRÁFICOS COMO REFERÊNCIAS NA OCUPAÇÃO DO TERRITÓRIO PAULISTA
}

\author{
O caso do morro do Lopo e os núcleos urbanos no "Caminho de \\ Atibaia", no século XVII
}

Ana Villanueva ${ }^{1}$

\section{1- O MORRO DO LOPO E SUAS REPRESENTAÇÕES CARTOGRÁFICAS}

A palavra "lopo" vem do latim "lupus" e significa lobo. Provavelmente este nome se deu pela enorme quantidade de lobos, guarás e outros, no local. ${ }^{2}$ Conforme relata Cassalho, ${ }^{3}$ foi também identificado na região um personagem chamado Lopo dos Santos Serra que apareceu em $1771 .^{4}$

Entretanto, como as citações a esse morro são anteriores ao século XVIII, a primeira hipótese é o mais provável.

O morro do Lopo (Fig. 1) aparece em relatos de viajantes e na cartografia desde o século XVI, mas torna-se fundamental no final do século XVII, quando as "Bandeiras" paulistas seguem de São Paulo a Minas passando por esta região.

Este morro transformou-se em uma espécie de bússola natural $l^{5}$ da expedição, por um caminho que margeava a zona geológica cristalina do norte com a serra da Mantiqueira ocidental. ${ }^{6}$

O caminho que passava pelo Lopo era conhecido como "Caminho de Atibaia" ou também como "Caminho que Vae para o Rio das Mortes". ${ }^{7}$

Para quem seguia em direção a Minas, partindo de São Paulo, era necessário atravessar a serra da Mantiqueira através de gargantas, que nada mais eram do

\footnotetext{
${ }^{1}$ Ana Aparecida Villanueva Rodrigues: arquiteta e urbanista; mestre pela FAU-USP, doutoranda em História pelo IFCH-UNICAMP, professora da Universidade Paulista; coordenadora de projetos do programa de requalificação do centro da cidade de São Paulo. email: villanuevarodrigues@yahoo.com.br ${ }^{2}$ Era comum nomear acidentes geográficos com a situação da realidade em que ele se encontrava à época. Pode-se exemplificar com: serra do frio, rio das mortes, sumidouro, serra das esmeraldas, etc...

${ }^{3}$ CASSALHO, Valter. Conselho Municipal de Turismo da Estância de Atibaia. Atibaia: 01/06/2005. Disponível em: http://comturatibaia.com.br/artigo.php?id=370. Acesso: 22 julho 2006

${ }^{4}$ Era comum nesta época que a referência geográfica se incorporasse ao nome da pessoa, como aconteceu com o sobrenome Masagão, para identificar as pessoas nascidas nesta cidade do século XVIII na Amazônia.

${ }^{5}$ SANTOS, Antonio da Costa. Campinas, das Origens ao Futuro. Compra e venda de terra e água e um tombamento na primeira sesmaria da Freguesia de nossa Senhora da Conceição das Campinas do Mato Grosso de Jundiaí (1732-1992). Campinas: Editora da UNICAMP, 2002, p. 62.

${ }_{7}^{6}$ Ibid., p. 61.

${ }^{7}$ O rio das Mortes era o referencial para a localização da cidade mineira de São João Del Rey.
} 
que passagens que possibilitavam a travessia, muitas vezes seguindo cursos de rios em vales.

No "Caminho de Atibaia", se atravessava a serra da Mantiqueira pela garganta do rio Cachoeira (Figs. 1 e 2), na região de Piracaia-SP.

A lógica geográfica contribuiu também na delimitação das divisas entre Estados, como mostra a Carta Corográfica da Capitania $^{8}$ de 1766 (Fig. 3), com as sete demarcações que existiram entre São Paulo e Minas, tendo sempre rios e morros como referências primordiais.

Nesta carta a última delimitação é explicitamente a do morro do Lopo. Este limite foi observado por viajantes até o início do século XIX:

O olhar de J. B. von Spix e C. F. P. von Martius observara, em 1817, 'o morrodo-lopo, coberto quase inteiramente de selvas escuras e, no mínimo, de três mil pés de altitude [sic] e que domina a serra', anotando este ponto especial para as demarcações territoriais entre paulistas e mineiros, realizadas pelo governo de morgado de Mateus. ${ }^{9}$

A cartografia do século XVIII é a mais expressiva na representação dos caminhos do ouro, com marcos geográficos e núcleos urbanos, apesar de ser a $2^{\mathrm{a}}$ metade do século VII o período mais importante de expedições paulistas rumo ao sertão mineiro, passando constantemente pela região do morro do Lopo.

O que parece ser uma contradição tem sua explicação no fato da coroa necessitar manter em sigilo a descoberta das minas.

Segundo Cortesão, da segunda metade dos Seiscentos até o primeiro quartel dos Setecentos, a escola portuguesa de cartografia havia decaído consideravelmente. Além disso, e em relação ao Brasil, côo os roteiros e traçados cartográficos que levavam às minas passaram a envolver imensas possibilidades econômicas, estas 'eram ciosamente guardas em segredo'(...). ${ }^{10}$

\footnotetext{
${ }^{8}$ Copiada pelo Major Umbelino Alberto de Campo Limpo em 1869, esta Carta Corográfica da Capitania de São Paulo, de 1766, é em tinta colorida, nanquim e aquarela, sobre papel canson com 60,5 x $48 \mathrm{~cm}$, com nota explicativa: Carta Corográfica da Capitania de São Paulo, em que se mostra a verdadeira situação dos lugares por onde se fizeram as sete principais divisões do seu Governo com o de Minas Gerais: A $1^{a}$ pelo Rio Grande; A $2^{a}$ pelo Morro do Cachumbu; A $3^{a}$ pelo alto da Serra da Mantiqueira; A $4^{a}$ outra vez pelo Cachumbu; A $5^{a}$ pelo Rio Verde; A $6^{a}$ pelo Sapocahy; A $7^{a}$ pelo Morro do Lopo, e estrada de Goyazes, o que mostra a linha cor amarela. Disponível para consulta em: http:/www.novomilenio.inf.br/santos/mapa41.htm. Acesso em 22 julho 2006.

${ }^{9}$ SANTOS, Antonio da Costa. Op. Cit., p. 62.

${ }^{10}$ CORTESÃO, Jaime. História do Brasil nos velhos mapas. Rio de Janeiro: Instituto Rio Branco, 1965, 1971, t. II, p. 161. In COSTA, Antônio Gilberto (org.). Os Caminhos do Ouro e a Estrada Real. Belo Horizonte: Editora UFMG; Lisboa: Kapa Editorial, 2005, p. 56
} 
Conforme explica Costa ${ }^{11}$, no final do século XVII encerra-se a fase de reconhecimento dos sertões com a chamada "Cartografia Sertanista", tendo como maior exemplo o MAPA Da maior parte Da Costa, e Sertão, do Brasil. Extraído do original do Pe Cocleo.

No século XVII, a cartografia produzida pelos Padres Matemáticos caracteriza-se por um maior rigor científico e registra com maior precisão os acidentes geográficos.

Encontra-se neste conjunto cartográfico sempre em destaque, o morro do Lopo, podendo ser exemplificada pelas:

Carta Chorografica da Capitania de São Paulo, 1766 (Fig. 4), com o morro do Lopo na Capitania de São Paulo e o morro do Cachumbu em Minas; e Carta Chorografica para intellig ${ }^{a}$. dos pontos das devizoes $Q$ tem havido entre a Capitania de S. Paulo e a de Minas Geraes, [s.d.] (Fig. 5), que marca em vermelho o morro do Lopo e o Jaraguá na Capitania de São Paulo e o Alto da Serra da Mantiqueira.

O morro do Lopo aparece em destaque ainda no mapa DEMONSTRAÇÃO de P.te da Diviza desta CAPITANIA com a de S. Paulo. Ca., em 1815 (Fig. 6).

No início do século XIX é produzido o Guia dos Caminhantes, por Anastasio de $\mathrm{S}^{\text {ta }}$ Anna, num total de 21 cartas:

Destes 21, a Carta $4^{a}{ }^{12}$ (Fig. 7) mostra a Capitania de São Paulo com caminhos e núcleos urbanos, sendo várias serras desenhadas e somente as principais nomeadas.

Observa-se nesta Carta $4^{a}$ que somente o morro do Lopo aparece como um marco isolado, pois os demais acidentes geográficos são as principais serras de grandes proporções como é o caso da Mantiqueira e do Viamão.

É interessante notar que a representação na cartografia até início do século XIX, de outros morros é rara ou inexistente, como é o caso do Jaraguá, próximo a São Paulo, e o Japi, próximo a Jundiaí, ambos em direção à Campinas, caminho este também em direção ao sertão de Minas e Goiás.

Esta constatação reforça o significado e a importância da região do morro do Lopo, e em especial deste marco geográfico, no quadro geral dos caminhos e povoações paulistas fundadas na direção de Minas.

\footnotetext{
${ }^{11}$ COSTA, , Antônio Gilberto (org.). Os Caminhos do Ouro e a Estrada Real. Belo Horizonte: Editora UFMG; Lisboa: Kapa Editorial, 2005, p. 64.

${ }^{12}$ Gûia de Caminhantes. Carta 4. ${ }^{a}$. Capitanîa de S. Paulo, dividida pelo circol pontedo de preto e lavado de carmizim vivo, e grosso. Onde se mostra seus mais notaveis Rios; Sítios; Povoaçoes; Capitaes; Serras; Estradas; Caminhos. Para o Senhor Capitaõ Pedro Francisco de Castro. Deliniada e Iluminada por Anastásio de S. ${ }^{\text {ta }}$ Anna. Pintor. Bahîa, e Anno. 1816.
} 


\section{2- OS CAMINHOS DAS "BANDEIRAS" E OS REFERENCIAIS GEOGRÁFICOS}

\section{1- Os principais caminhos para Minas e o caso do morro do Lopo}

Desde o século XVI, expedições abriram vários caminhos em busca de riquezas principalmente em território mineiro. Em um primeiro momento as tentativas de descobrimento vinham do nordeste em direção ao sertão, com as "Entradas". Temos os principais caminhos descritos por Antônio Gilberto Costa: ${ }^{13}$

Entre 1553 e 1554 aconteceu a "Entrada" de Francisco Bruzza de Spinosa (Fig. 8), a partir de Porto Seguro, para tentar se chegar a "Serra Resplandecente". Um primeiro relato do sertão se inicia, tendo sempre marcos geográficos como referenciais, mesmo que para demonstrar a dificuldade que estes impunham à expedição. Segundo descrição do jesuíta João de Aspilcueta Navarro, que acompanhou Espinosa, os sertões eram 'intratáveis a pés portugueses, dificultosíssimos de penetrar (...), tendo que atravessar inúmeras lagôas e rios (...), os montes fragrosíssimos, os matos espesíssimos, que chegavam a impedirIhes o dia'.14

Em 1561, para se tentar alcançar a região de Sabarabuçu (região da atual Sabará), no território de Minas Gerais, ocorreu a "Entrada" de Dom Vasco Rodrigues Caldas, sendo seguida da de Martim Carvalho em 1568. E assim, sucessivamente várias "Entradas" foram organizadas durante o século XVI, com roteiros partindo principalmente da Bahia e do Espírito Santo.

Por outro lado as "Bandeiras" paulistas, no final do século XVI, abriram alguns caminhos partindo de São Paulo de Piratininga incentivadas pelo Governador-Geral das capitanias do sul, Dom Francisco de Sousa.

Capistrano de Abreu destaca a posição geográfica estratégica de São Paulo que

\footnotetext{
${ }^{13}$ COSTA, Antônio Gilberto (org.). Op. Cit., pp. 46-47.

${ }^{14}$ BARREIROS, Eduardo Canabrava. Roteiro das Esmeraldas: A Bandeira de Fernão Dias Pais. Rio de Janeiro: José Olympio, 1979. v. 188, p. 133 (Documentos Brasileiros). In COSTA, Antônio Gilberto (org.). Ibid., p. 46.
} 
(...) impelia-a para o sertão, para os dois rios de cuja bacia se avizinha, o Tietê e o Paraíba do Sul, teatros prováveis das primeiras bandeiras, que tornaram logo famoso o temido nome paulista. ${ }^{15}$

Costa $^{16}$ relata que um dos primeiros registros de expedições partindo de São Paulo em 1596, é a que foi chefiada pelo Capitão-Mor João Pereira de Sousa Botafogo, e se configura pelo deslocamento seguindo o Vale do Rio Paraíba.

E é nessa trilha que se configura um dos mais importantes caminhos partindo de São Paulo, que chegava a Minas, a partir da bifurcação em Guaratinguetá, atravessando a Serra da Mantiqueira pela garganta do Embaú, ${ }^{17}$ atual cidade de Cruzeiro no Estado de São Paulo (Figs. 6, 8, 9, 10 itens 8, 9 e 11). Também ficou conhecido como "Caminho Velho".

Esse caminho, entre outros, fazia parte de trilhas indígenas que já se encontravam dispostas segundo o sentido dos cursos de água, atravessando os campos abertos ou aproveitando as gargantas naturais, que permitiam a passagem de uma bacia para outra. ${ }^{18}$ Os mais conhecidos nesta época eram os: "Caminho dos Guaianases" e "Caminho dos Goytacases".

Existia um outro caminho importante que aproveitava também uma trilha indígena, que fez com que as vilas paulistas do Vale do Paraíba se comunicassem com o Rio de Janeiro através de Paraty, no século XVII. Este derivava da bifurcação do caminho paulista para Minas através da garganta do Embaú, só que no sentido oposto, pois seguia a direção do litoral, passando pelos campos de Cunha e pela Serra do Mar (Fig. 10, itens 11, 15 e 16).

A descoberta dos rios Sapucay e o Verde, no final do século XVI, foi de fundamental importância para ligação à Goiás (Fig. 10, itens 5 e 6).

Conforme Costa, ${ }^{19}$ em 1596, membros da expedição de Martim Correia de Sá perseguiram índios tamoios próximo a esses rios, e ainda no mesmo ano a Bandeira de João Botafogo, já mencionada, alcançou as regiões dos rios Verde e Sapucahy, após travessia da Mantiqueira pela garganta do Embaú, passando pelo morro do Cachambú em direção ao território Goiano (Fig. 10, itens 1, 3, 9, 12 e 13).

\footnotetext{
${ }^{15}$ ABREU , João Capistrano de. Caminhos Antigos e Povoamento do Brasil. Rio de Janeiro: Civilização Brasileira, $4^{\mathrm{a}}$ edição, 1975, p. 34.

${ }_{17}^{16}$ COSTA, Antônio Gilberto (org.). Op. Cit., p. 52.

${ }^{17}$ Ibid., p. 43.

${ }^{18}$ Ibid., p. 43.

${ }^{19}$ Ibid., pp. 52-53.
} 
Em 1602, foi feito o mesmo caminho passando por estes rios em sentido contrário: a expedição de Diogo Gonçalves Laço e Francisco Proença chegou em Minas a partir do Caminho de Mogi-Guaçu e voltou para São Paulo pelo "Caminho Velho" (Fig. 10).

Esse traçado que ligava Goiás a Minas e que passava pelos rios Verde e Sapucahy propiciou o surgimento de uma bifurcação que se ligava ao morro do Lopo, e iria se transformar posteriormente, em importante caminho de "Bandeiras" (Fig. 5 e Fig. 10 , itens 4 e 14).

Mesmo com algumas iniciativas esparsas, o início do século XVII não propiciou a expansão de Caminhos rumo à Minas, pois, aliada à situação precária de alimentação, em 1624 um Mandado do Capitão-mór Álvaro Luiz do Valle, proibia '...sahir gente para o sertão obrigando a gente de armas a se aprestar para a defeza da Capitania...', os paulistas foram obrigados a continuar inativos no bandeirismo. $^{20}$

É somente com o fim da união das coroas ibéricas (1580 - 1640), as "Bandeiras" paulistas voltam a ser organizar em direção busca do sonho de encontrar riquezas.

A primeira que se tem referência é a de João Pereira em 1643, sendo seguida em 1655 pela de Álvaro Rodrigues, e a partir da década de 60 muitas outras "Bandeiras" saíram em busca de ouro e esmeraldas rumo à serra de Sabarabuçu.

A "Bandeira" de Lourenço Castanho Taques, em 1668, foi importante para consolidação dos caminhos para Minas, conforme explica Costa, ${ }^{21}$ pois enfrentou os ferozes índios cataguazes e araxás. O caminho desta expedição pode ter sido o do Morro do Lopo, porém existem divergências.

Em 1672, D. Pedro II (de Portugal) encarregou Fernão Dias Pais Leme de encontrar as minas. Recebe a nomeação de governador de toda a gente de guerra e outra qualquer que tiver ido ao descobrimento das minas de pratas e esmeraldas. ${ }^{22}$

Essa "Bandeira" partiu em 21 de junho de 1674 na direção de Sabarabuçu. Fizeram parte da expedição 674 homens, entre os quais: Garcia Rodrigues Pais (filho de Fernão Dias), José Dias Pais (filho bastardo) Manuel da Borba Gato (genro) e o Capitão Mathias Cardoso de Almeida (comandante da expedição).

\footnotetext{
${ }^{20}$ Ibid., p. 52.

${ }^{21}$ Ibid., p. 54.

${ }^{22}$ QUEIROZ, Mirna. Fernão Dias Pais Leme.Disponível em:

http://www.vidaslusofonas.pt/fernao_pais_leme.htm. Acesso em: 22 julho 2006.
} 
Segundo a tradição e os cronistas, faleceu Fernão Dias, em 1681, nas margens do rio das Velhas, quando regressava das explorações na região banhada pelos rios Jequitinhonha e Araçuaí. ${ }^{23}$

O exato caminho de ida e volta da expedição de Fernão Dias é controverso: sabe-se que passou por Paraopeba e Sumidouro até Serro Frio (local que ligava Minas a Bahia), porém a travessia da serra da Mantiqueira pode ter sido feita pelo Embaú no "Caminho Velho", que acompanhava o Vale do Paraíba, ou pela região de Atibaia e Camanducaia, passando pelo morro do Lopo.

Pedro Taques ${ }^{24}$ aponta os pioneiros do desbravamento da estrada de São Paulo para Minas, através de São João de Atibaia, descrevendo que em 1673, que as tropas de Fernão Dias Pais haviam entrado nos sertões em direção a Sabarabuçu por este caminho.

Por outro lado, Costa ${ }^{25}$ relata que a "Bandeira" de Fernão Dias de 1674 deslocou-se pelo vale do Paraíba, atravessando a Mantiqueira, e passando por Ibiturana, Paraopeba, Sumidouro, Roça Grande, Itacambira, Itamarandiba, Esmeraldas, Mato das Pedrarias e Serro Frio.

A possibilidade da existência de passagem de "Bandeiras" pelo caminho do Lopo, vem da expedição de D. Rodrigo de Castelo Branco. Em 12 de março de 1681, D. Rodrigo partiu de São Paulo em direção a Sabarabuçu passando por Juquery, no "Caminho de Atibaia", também denominado como "Caminho que Vae para o Rio das Mortes" $^{\prime 26}$ (Figs. 4, 5, 7, 10 e 11).

Chegou em Atibaia em 24 de março e a partir daí seguiu o curso do Camanducaia entrando em Minas, tendo a Serra do Lopo à sua direita. Em meados de abril alcançou a região do Sapucahy e por volta de 15 de junho chegou ao Arraial de São Pedro de Paraopeba. Nesse arraial encontrou-se D. Rodrigo com Garcia Rodrigues, que retornava para São Paulo com os restos mortais de Fernão Dias e as famosas pedras verdes encontradas. ${ }^{27}$

Tornam-se freqüentes as expedições nesta época até que se chegue ao

\footnotetext{
${ }^{23}$ PRADO, Paulo. CALIL, Carlos Augusto (org.). Paulística etc. São Paulo: Companhia das Letras, $4^{\mathrm{a}}$ ed. 2004, pp. 190-101.

${ }^{24}$ LEME, Pedro Taques de Almeida Paes in SANTOS, Antonio da Costa. Op. Cit., p. 60.

${ }^{25}$ COSTA, Antônio Gilberto (org.). Op. Cit., p. 54.

${ }^{26}$ O Rio das Mortes é localizado na cidade de São João del Rei.

${ }^{27}$ COSTA, Antônio Gilberto (org.). Op. Cit., p. 55.
} 
(...) descobrimento das opulentas, e rendosas Minas de Gerais, conseguidos à custa dos seus descobridores os Paulistas e Carlos pedroso da Silveira e Bartolomeu Bueno da Siqueira pelos anos de mil seiscentos e noventa e cinco, apresentavam as primeiras mostras de Ouro deste Sertão chamado até aquele tempo de Cataguazes e Sabarabuçu, que a corrupção do mesmo tempo fez o seu nome conhecido pelo de Minas de Sabará. ${ }^{28}$

Em 1697, Garcia Rodrigues Paes recebeu correspondência real, estando por ocasião nos sertões das Geraes, segundo a qual reconhece ter sido ele o primeiro que descobriu o ouro de lavagem dos Ribeiros, que correm para a Serra de Sabarabasú. ${ }^{29}$

A guerra dos emboabas, no início do século XVIII, foi vencida pelos portugueses contra os paulistas para controle do ouro mineiro, encerrando aí o ciclo das "Bandeiras" paulistas rumo ao sertão das Minas. Nesta época os principais caminhos já estavam desenhados.

Mafalda Zemella ${ }^{30}$ estipulou a existência de três importantes caminhos paulistas para se chegar à Minas:

1- O "Caminho Velho de São Paulo", que acompanhava o Vale do Paraíba, passando por Mogi das Cruzes, Taubaté, Pindamonhangaba e Guaratinguetá, atravessando a serra da Mantiqueira em Cruzeiro pela garganta do Embaú; 2- O "Caminho de Atibaia" ou do Sapucaí, que passava por Juquery, Atibaia, rio Cachoeira, morro do Lopo, transpondo a serra da Mantiqueira pelo Vale do Camanducaia (Sertão do Manducaya); 3- O "Caminho dos Guaianazes", passando pelo vale do Mogi-Guaçu e pelo morro do Gravi.

Não foram encontrados registros da primeira expedição que passou pelo "Caminho de Atibaia" e em qual direção ela se deu, mas com certeza era um caminho conhecido no século XVII para se alcançar Minas.

Essa importância é constatada pela quantidade de núcleos urbanos surgidos nesta época e que serviam de entrepostos comerciais, reforçando a importância de São

\footnotetext{
${ }^{28}$ LEME, Pedro Taques de Almeida Paes. Notícias das Minas de São Paulo e dos sertões da mesma Capitania. Introdução e notas de Afonso de E. Taunay. São Paulo: Publicações comemorativas sob o alto patrocínio da Comissão do IV Centenário da Cidade de São Paulo, 1953, p. 89.

${ }^{29}$ LEME, Pedro Taques Paes. Informação sobre as minas de São Paulo e a expulsão dos Jesuítas do Collegio de São Paulo. Com um estudo sobre a obra de Pedro Taques por Affonso de E. Taunay. São Paulo: Companhia Melhoramentos de São Paulo, [19--], p. 111. In COSTA Antônio Gilberto (org.). Op. Cit.., p. 55.

${ }^{30}$ ZEMELLA, Mafalda P. O Abastecimento da Capitania das Minas Gerais no Século XVIII. São Paulo: Tese de Doutoramento apresentada à cadeira de História da Civilização Brasileira da Faculdade de Filosofia, Ciências e Letras da U.S.P, 1951.
} 
João de Atibaia que funcionava como entroncamento de vias de comunicações com as regiões do sertão e das minas, ${ }^{31}$ fazendo com que se a partir daí se derivassem outros caminhos.

\section{3- A OCUPAÇÃO HUMANA E A FORMAÇÃO DOS NÚCLEOS URBANOS NA REGIÃO DO MORRO DO LOPO}

\section{1- A ocupação indígena}

Existem registros da presença indígena na região desde o século XVI.

Capistrano de $\mathrm{Abreu}^{32}$ diz que os índios Maramumis e Guarulhos (tribos dos Guaianazes) passaram por gargantas do rio Cachoeira e Muquém na atual cidade de Piracaia. ${ }^{33}$

Os jesuítas estabeleceram o controle dos índios guarulhos ou guarus ${ }^{34}$ nas margens do rio Tietê, Nossa Senhora da Conceição dos Guarulhos, e no sertão ${ }^{35}$ paulista, no

aldeamento $^{36}$ de São João de Atibaia (Fig. 12).

\footnotetext{
${ }^{31}$ Ibid., p. 82

${ }^{32}$ ABREU, Capistrano. Capítulos de História Colonial (1500-1800). Brasília: Editora Universidade de Brasília, $5^{\text {a }}$ edição, 1963, p. 276. In CASSALHO, Valter. O casamento na tradição indígena brasileira. Conselho Municipal de Turismo da Estância de Atibaia. Atibaia: 01/06/2005. Disponível em: http://comturatibaia.com.br/artigo. Acesso em: 22 julho 2006.

${ }^{33}$ Ibid.

${ }^{34}$ Para Teodoro Sampaio o nome Guaru significa o indivíduo que come, o comedor, em alusão ao formato do peixe desse nome, então os índios guarus tinham esse nome por serem barrigudos. A palavra guaru foi aos poucos se alterando até resultar em Guarulhos. Disponível em: http://www.citybrazil.com.br/sp/guarulhos/historia.htm. Acesso em 22 julho 2006.

35 A palavra sertão vem de "desertão", ou seja,terras sem ocupação.

${ }^{36}$ Portugal criou os "aldeamentos", que eram núcleos concentrados de população em sua maioria indígena, com controle religioso, principalmente jesuítico, com a finalidade de diferenciar-se das "aldeias", civilizando os índios e tornando-os aliados úteis. In TORRÃO FILHO, Amílcar. Paradigma do caos ou cidade da conversão ? : a cidade colonial na América Portuguesa e o caso de São Paulo na administração do Morgado de Mateus (1765-1775). Dissertação de Mestrado em História. Campinas: UNICAMP-IFCH Departamento de História, 2004, p. 232.
} 
(...) o Padre Manuel Nunes de Siqueira, vigário de S. Paulo, conduziu e localizou [os índios guarulhos] "no sítio chamado Atibaia", isso no ano de 1565 (Aureliano Leite). ${ }^{37}$

Os índios guarulhos chamavam este local de "ty-baia", que significava "manancial saudável".

Existem outros registros de índios no local, conforme explica Cassalho, ${ }^{38}$ descrevendo a história do pirata inglês Antonio Knivet, que esteve na aldeia dos Tamoios em aproximadamente 1598, nas imediações ou confluência do Rio Jaguari com o rio do Peixe (maior afluente da margem esquerda do Jaguari), próximo ao local onde hoje está Igaratá. ${ }^{39}$

Knivet fazia parte da expedição do famoso pirata Cavendish, e escreveu a história de sua viagem que foi publicada em inglês no início do século XVIII. ${ }^{40}$

Cavendish foi náufrago e prisioneiro de Salvador Correa de Sá. Antonio Knivet integrou a bandeira de Martim de Sá, saindo do Rio de Janeiro em 1597, passando por Parati, Ubatuba, até o planalto. Ficaram aproximadamente um mês nas proximidades de São José dos Campos. A situação era de fome, pois nas aldeias só havia batata, e já haviam morrido 180 homens. A desordem e a indisciplina completaram o desastre. Nas margens do Jaguary dispersou-se a expedição e por outros trilhos começou a viagem de regresso. ${ }^{41}$ Antonio Knivet relatou sua viagem dizendo que desceu por uma semana o rio Jaguari com bandeirantes que procuravam seus inimigos Tamoios. A partir daí caminharam rumo sudoeste:

(...) fomos ter a uma montanha grande e selvagem e chegamos a um lugar cujo solo seco e de uma cor escura, crespo de colinas e penhascos, onde vários ribeiros tinham ai suas origens. ${ }^{42}$

A montanha era o morro do Lopo e, conforme Teodoro Sampaio, o rio seria o Guaripocaba de Bragança Paulista. ${ }^{43}$

\footnotetext{
${ }^{37}$ Disponível em: http://www.citybrazil.com.br/sp/guarulhos/historia.htm. Acesso em 22 julho 2006.

${ }^{38}$ CASSALHO, Valter. Op. Cit.

${ }^{39}$ SAMPAIO, Theodoro. São Paulo no século XX e outros ciclos históricos. São Paulo: Editora Vozes, 1978. In CASSALHO, Valter. Ibid.

${ }^{40}$ MENEZES, Raimundo de. Aconteceu no Velho São Paulo. São Paulo: Coleção Saraiva, 1954.

Disponível em: http://www.pitoresco.com.br/historiarocha03a.htm. Acesso: 22 julho 2006.

${ }^{41}$ NALINI, José Renato. A Saga do Bandeirante. Disponível em: http://www.jj.com.br/ji2opiniao/opiniao16072006-01.html. Acesso 22 julho 2006.

${ }^{42}$ KNIVET, Antonio in CASSALHO, Valter. Op. Cit.
} 
Nos relatos de Knivet, este diz que permaneceu entre os canibais tamoios por um ano e onze meses, e ficou vivo porque os índios acreditavam que ele era francês. Como os tamoios eram aliados dos franceses contra os portugueses, devoraram apenas os bandeirantes. Além disso, Knivet ajudou os tamoios contra a tribo dos temiminós. ${ }^{44}$

Na região entre Camanducaia, Itapeva, Extrema, Joanópolis, Vargem, Piracaia, Bom Jesus, Nazaré, Igaratá, São José dos Campos e região, peregrinavam então os índios Tamoios, Temiminós e os Tupiniquins. ${ }^{45}$

\section{2- A organização de povoamentos ao longo dos caminhos das "Bandeiras"}

Para exercer as posições junto às "Bandeiras", os paulistas luso-brasileiros eram indispensáveis para entrar no mato, passar a nado ribeirões, e pantanais, de que está cheio. ${ }^{46} \mathrm{O}$ bandeirismo era feito de forma a firmar relações de sangue, constituindo principalmente famílias luso-tupis. A personalidade deste paulista era fundamental para o objetivo a se alcançar, ou seja, a penetração do sertão.

Sobre este caráter paulista, existem estudos importantes como o de Capistrano de Abreu ao citar um relato de época:

(...) os mamelucos, conforme os graus da mescla, têm a pele quase cor de café, amarela ou quase branca. Traem a mistura indiana antes de tudo a cara larga, com maçãs salientes, olhos pretos e não grandes e certa incerteza de olhar. A estatura elevada e ao mesmo tempo larga, feições fortes, sentimento de liberdade e desassombro, olhos brunos, ou raramente azuis, cheios de fogo e afoiteza, cabelo cheio, preto e liso, musculatura reforçada, decisão e rapidez nos movimentos são, aliás, os principais característicos na fisionomia dos paulistas. Em geral pode-se atribuir-Ihes um caráter melancólico, misturado com alguma coisa de colérico (...). ${ }^{47}$

\footnotetext{
${ }^{43}$ SAMPAIO, Teodoro in CASSALHO, Valter. Ibid.

${ }^{44}$ CASSALHO, Valter. Ibid.

${ }^{45}$ Ibid.

${ }^{46}$ HOLANDA, Sérgio Buarque de. Monções. São Paulo: Editora Alfa Omega, $2^{\mathrm{a}}$ edição, 1976, p. 47.

${ }^{47}$ ABREU, Capistrano. Capítulos de História Colonial (1500-1800). Brasília: Editora Universidade de Brasília, $5^{\text {a }}$ edição, 1963, p. 276.
} 
Paulo Prado também fala do caráter do mameluco, através de relato de um mineiro não identificado:

(...) do cruzamento do forte sangue português quinhentista, dos franceses, castelhanos e flamengos com as cunhãs, o mameluco surgiu perfeitamente aparelhado para o seu destino histórico. A montanha isoladora dos contágios decadentes do litoral; a atitude sempre sobressaltada de quem vivia na orla das imensas matas virgens, sombrias e espessas; a convivência diária e íntima com o gentio da terra de quem falava correntemente a língua; a feliz situação geográfica e topográfica que o locava à margem e nas proximidades de grandes rios descendo para o interior das terras; a aspereza fortificante de um clima de bruscas variações, em que às geadas das manhãs claríssimas sucedem sóis abrasadores do meio dia, todos esses fatores conjugados criaram um admirável exemplar humano, belo como um animal castiço (...). ${ }^{48}$

Porém, mesmo tendo os mamelucos já se adaptado e vencido várias dificuldades do sertão, a situação das bandeiras por vezes chegava ao limite extremo, principalmente pela falta de comida. Conforme Nalini, ${ }^{49}$ quando os bandeirantes não tinham o que comer, roíam as raízes das árvores, comiam lagartos, cobras e os sapos. Se não tinham o que beber, mascavam folhas silvestres, frutos acres do campo e sangue dos animais. Por isso é que em inúmeros inventários da época, é comum a expressão "Morto no sertão". 50

A necessidade do gado e a dificuldade da chegada do mesmo através das trilhas de São Paulo, fizeram com que o gado fosse criado através do Rio São Francisco, chegando às Minas pela Bahia, cujo caminho foi se encontrar com o das "Bandeiras".

Muitos paulistas transformaram-se em criadores de gado e não mais retornaram à São Paulo, como foi o caso de Domingos Jorge Velho. Capistrano de Abreu confirma:

Ainda antes do descobrimento das minas, sabemos que nas ribeiras do rio das Velhas e do São Francisco havia mais de cem famílias paulistas entregues à criação de gado. ${ }^{51}$

\footnotetext{
${ }^{48}$ PRADO, Paulo. Op. Cit.

${ }^{49}$ NALILI, José Renato. Op. Cit.

${ }^{50}$ Ibid.

${ }^{51}$ Ibid. In http://www.multirio.rj.gov.br/historia/modulo01/setao.html. Acesso 22 julho 2006.
} 
Em 1618, Ambrósio Fernandes Brandão, escreveu os seis Diálogos das Grandezas do Brasil e dizia que o problema da mineração era a dificuldade de alimentar as pessoas e não a de encontrar metais, e fazia uma estratégia:

O primeiro que se devia fazer antes de bulir nelas, depois de estarem certos que eram de proveito, houvera de plantarem-se muitos mantimentos ao redor do sítio onde elas estão e como os houvesse em abundância tratar-se-ia da lavoura das minas; mas isto se faz pelo contrário, porque sem terem mantimento entenderam em tirar o ouro e como as minas estão muito pelo sertão os que vão levam de carreto o mantimento necessário e como se lhe acaba tornam-se e deixam a lavoura que tinham começado. E esta cuido que é a verdadeira causa de darem as ditas minas pouco de $\mathrm{si}^{52}$

Fernão Dias Pais, ${ }^{53}$ fazia o planejamento referente à alimentação de seu bando, e recomendava que se fizessem lavouras ao redor das minas, e que também era necessário muito gado, para que a bandeira não ocorresse de forma aleatória. ${ }^{54}$

Dizia com relação às minas:

O primeiro que se devia fazer antes de bulir nelas, depois de estarem certos que eram de proveito, houvera de plantarem-se muitos mantimentos ao redor do sítio onde elas estão e como os houvesse em abundância tratar-se-ia da lavoura das minas; mas isto se faz pelo contrário, porque sem terem mantimento entenderam em tirar o ouro e como as minas estão muito pelo sertão os que vão levam de carreto o mantimento necessário e como se lhe acaba tornam-se e deixam a lavoura que tinham começado. E esta cuido que é a verdadeira causa de darem as ditas minas pouco de si. ${ }^{55}$

E foi desta forma que Fernão Dias organizar a sua famosa expedição de 1674, mandando na frente para a região do Sumidouro, Bartolomeu da Cunha Gago e Matias Cardoso de Almeida, com a missão de plantar roças de mantimentos, para que quando a expedição chegasse a este local pudesse permanecer e reabastecer.

\footnotetext{
${ }^{52}$ BRANDÃO, Ambrósio Fernandes. Diálogos das Grandezas do Brasil. 1618. In ABREU, Capistrano. Capítulos de História Colonial (1500-1800). Brasília: Editora Universidade de Brasília, $5^{a}$ edição, 1963, p. 187.

${ }^{33}$ Fernão Dias Pais Leme, nasceu em São Paulo em 1608, morrendo no sertão em 1681, foi um bandeirante paulista conhecido como $O$ Caçador de Esmeraldas. Desbravador dos sertões do Brasil, era oriundo de família rica e influente na sociedade seiscentista paulistana, filho de Pedro Dias Leme e Maria Leite.

${ }_{55}^{54}$ ABREU, Capistrano. Capítulos de História Colonial (1500-1800). Op. Cit., p. 189.

${ }^{55}$ Ibid.
} 
A fundação de arraiais era fundamental para a sobrevivência das expedições, assim esta "Bandeira" fundou o arraial de Ibipiruna (Serra Negra), o arraial de Santana (no rio Paraopeba) e o de São João de Sumidouro (Pedro Leopoldo).

A partir da chegada ao arraial de Sumidouro, Fernão Dias solicita auxílio ao Governador e a sua esposa devido às baixas sofridas no caminho, e ficou neste local cultivando cereais e criando pequenos animais domésticos. Foi também aí que seu filho José Dias preparou uma insurreição e sendo descoberto foi morto.

Desta forma, os caminhos existentes a partir de São Paulo, propiciaram o surgimento de uma rede de povoados que ocuparam o sertão, criando-se entrepostos comerciais principalmente nos locais de pousos das tropas. O local destes povoados dava-se em pontos estratégicos ao longo dos caminhos, onde a natureza era mais acolhedora e propícia para tal.

Exemplo claro disso é o caso da Freguesia de Nossa Senhora da Conceição das Campinas do Mato Grosso de Jundiaí (Campinas), cuja primeira povoação surge ao redor de três "campinas" surgidas no interior de uma mata densa e de difícil penetração, ao longo de um caminho vindo de Jundiaí em direção a Goiás. ${ }^{56}$

\section{3- Núcleos urbanos: Freguesias e Vilas}

Segundo Paulo Prado, ${ }^{57}$ nos caminhos paulistas das minas reuniu-se a população escassa da capitania, em vilas e arraiais.

A partir desses núcleos urbanos se estabelecia

(...) uma diretriz sertão adentro, através do que Ratzel nomeou, pela força das tendências antropogeográficas, 'área de transito' dos povos. Parnaíba e Itu apontavam para Mato Grosso; Jundiaí, para Goiás; Sorocaba, para os campos onde já surgia Curitiba; as vilas do Paraíba do Sul, para as próximas Minas Gerais (...). ${ }^{58}$

Da mesma forma, Capistrano de Abreu afirma que as vilas paulistas não eram populosas:

\footnotetext{
${ }^{56}$ RODRIGUES, Ana Aparecida Villanueva Rodrigues. Preservação como Projeto. Área do pátio ferroviário central das antigas Cia. Paulista e Cia Mogiana-Campinas-SP. Dissertação de Mestrado. São Paulo: FAU-USP, 1997.

${ }_{57}^{57}$ PRADO, Paulo. Op. Cit. p. 197.

${ }^{58}$ Ibid.
} 
(...) além de Sorocaba, ou de Itu, ou de Guaratinguetá começa o deserto, a população termina bruscamente, como montanha em talhado (...). ${ }^{59}$

No século XVII, também eram poucos os povoamentos na estrada do "Caminho que Vae para o Rio das Mortes", apontando para o morro do Lopo, como relata Antonio da Costa Santos. ${ }^{60}$

São João de Atibaia (Atibaia) era a porta de entrada e o mais importante núcleo seguido do de Nossa Senhora de Nazaré de Atibaia (Nazaré Paulista) e Jaguary (Bragança Paulista) (Figs. 4 e 13).

A constituição das principais núcleos urbanos da região do morro do Lopo teve a seguinte cronologia:

1- Atibaia: em 1665, foi construída uma capela de São João Batista dando origem a São João do Atibaia, ${ }^{61}$ passando a ser Paróquia em $1747 .{ }^{62}$ Foi elevada à Vila em $1769,{ }^{63}$ e em 1864 à categoria de Cidade.

2- Nazaré Paulista: a construção da capela primitiva de Nossa Senhora de Nazaré de Atibaia foi efetuada em 1676, tendo sido elevada a vila em 1850 e a Cidade em $1906 .^{64}$

3- Bragança Paulista: em 1763 foi construída a Capela de Nossa Senhora da Conceição, próximo ao morro do Lopo, que deu origem ao povoado de Conceição do Jaguary. Em 1797, torna-se vila com o nome de Vila Nova Bragança e em 1856 Cidade de Bragança. ${ }^{65}$

Existiam, portanto, núcleos urbanos referenciais, ${ }^{66}$ a partir dos quais orbitavam outros núcleos sendo a existência de todos, conseqüência do traçado dos caminhos e de seus pousos, assim como dos marcos geográficos e econômicos.

A hierarquia das cidades ao longo dos caminhos fica explícita na cartografia principalmente do século XVII e início XIX, dada a escassez da mesma no século XVII, já explicada anteriormente, e conforme decorre o tempo, sua representação torna-se cada vez mais elaborada.

\footnotetext{
${ }^{59}$ ABREU , João Capistrano de. Caminhos Antigos e Povoamento do Brasil. Op. Cit. p. 65.

${ }^{60}$ SANTOS, Antonio da Costa. Op. Cit.,p. 61.

${ }^{61}$ Ibid.

${ }^{62}$ Disponível em: http://www.atibaia.com.br/cidade/historia02.asp. Acesso em 22 julho 2006.

${ }^{63}$ TORRÃO FILHO, Amílcar. $O$ 'milagre da onipotência' e a dispersão dos vadios: política urbanizadora e civilizadora em São Paulo na administração do morgado de Mateus (1765-1775). Porto Alegre: EDIPUCRS, 2005, p. 163.

${ }^{64}$ Disponível em: http://www.nazarepaulista.com.br/hist.html. Acesso em 22 julho 2006.

${ }^{65}$ Disponível em: http://www.diocesedebragança.org.br/historia.shtml. Acesso em 22 julho 2006.

${ }^{66} \mathrm{Na}$ estrada de Goyazes, ao norte de São Paulo a situação era a mesma, e Jundiaí era o principal povoamento, seguido de Mogi-Guaçu.
} 
Pode-se observar nitidamente esta situação na Carta Chorografica de 1766 (Fig. 4) e no Guia de Caminhantes de 1816 (Fig. 14). Neste último, os principais ítens de legenda apresentados constitui-se de: Cidades, Villas, Arrayaes, Freguezias e Povoações (estas duas com o mesmo status), Capelas, Simiterios, Fazendas e Sítios. (Figs. 7 e 14)

$\mathrm{Na}$ representação gráfica, a quantidade de prédios demonstra o tamanho e a importância do local. Interessante notar que a distinção entre Arrayaes e Freguezias no Guia de Caminhantes (Fig. 14), se dá pelo fato do primeiro não possuir uma cruz no alto do prédio desenhado, o que vem a qualificar o local.

O final do século XVII e começo do XVII foi marcado por mudanças na ocupação do território paulista, na extensão dos caminhos abertos, pois

(...) após as descobertas das minas, se tratou de povoar os territórios antes tantas vezes talados pela bandeiras, as vilas do Tietê e do Paraíba do Sul ficam exaustas. $^{67}$

Na $2^{a}$ metade do século XVIII ocorreu a grande mudança política, no reinado de dom José I (1750-1777), sob o comando do marquês de Pombal, que ordenou fundar cidades dentro com um plano urbano de desenho reticulado e pré-definido e ocupou o eixo centro-sul da colônia transferindo a capital para o Rio de Janeiro.

Entretanto, estas cidades fundadas por Pombal, na sua maioria já existiam anteriormente ao longo dos caminhos ou como arraiais, povoados, e algumas principais até como freguezias.

Isto demonstra a importância do século XVII em um desenho macro do território paulista, estando a capitania de São Paulo, no século XVIII, já com uma característica física - espacial delineada.

E esta configuração espacial, de "construção" cultural, fortemente definida pela paisagem natural, organizadora do território paulista.

\footnotetext{
${ }^{67}$ ABREU , João Capistrano de. Caminhos Antigos e Povoamento do Brasil. Op. Cit. p. 65.
} 


\section{BIBLIOGRAFIA}

ABREU, João Capistrano de. Capítulos de História Colonial (1500-1800). Brasília: Editora Universidade de Brasília, 5a edição, 1963.

Caminhos Antigos e Povoamento do Brasil. Rio de Janeiro: Civilização Brasileira, 4a edição, 1975.

BOXER, Charles R. O Império marítimo português (1415-1825). São Paulo: Cia das Letras, 2002.

CONDEPHAAT. Processo de tombamento do núcleo histórico da cidade de Piracaia. São Paulo: 2001.

COSTA, Antônio Gilberto (org.). Os Caminhos do Ouro e a Estrada Real. Belo Horizonte: Editora UFMG; Lisboa: Kapa Editorial, 2005.

HOLANDA, Sérgio Buarque de. Monções. São Paulo: Ed. Alfa Omega, 2a ed., 1976.

LEME, Pedro Taques de Almeida Paes. Notícias das Minas de São Paulo e dos sertões da mesma Capitania. Introdução e notas de Afonso de E. Taunay. São Paulo: Publicações comemorativas sob o alto patrocínio da Comissão do IV Centenário da Cidade de São Paulo, 1953.

NOVAIS, Fernando A. História da vida privada no Brasil 1. Cotidiano e vida privada na América portuguesa. São Paulo: Cia das Letras, 1997. 
PRADO, Paulo. Paulística etc. $4^{a}$ edição revista e ampliada por Carlos Augusto Calil. São Paulo: Companhia das Letras, 2004.

RODRIGUES, Ana Aparecida Villanueva. Preservação como Projeto. Área do pátio ferroviário central das antigas cia. Paulista e cia. Mogiana, Campinas-SP. Dissertação de Mestrado. FAU-USP, 1997.

SAMPAIO, Theodoro. São Paulo no século XX e outros ciclos históricos. São Paulo: Ed. Vozes, 1978.

SANTOS, Antonio da Costa. Campinas da Origem ao Futuro. Compra e venda de terra e água e um tombamento na primeira sesmaria da Freguesia de Nossa Senhora da Conceição das Campinas do Mato Grosso de Jundiaí (1732-1992). Campinas: Editora da UNICAMP, 2002.

TORRÃO FILHO, Amílcar. O 'milagre da onipotência' e a dispersão dos vadios: política urbanizadora e civilizadora em São Paulo na administração do morgado de Mateus (1765-1775). Porto Alegre: EDIPUCRS, 2005.

- Paradigma do caos ou cidade da conversão ? : a cidade colonial na América Portuguesa e o caso de São Paulo na administração do morgado de Mateus (1765-1775). Dissertação de Mestrado em História. Campinas: UNICAMP-IFCH-Departamento de História, 2004.

VIDAL, Laurent. Mazagão. La ville qui traversa l'atlantique. Du Maroc à I'Amazonie(1769-1783). France: Aubier Collection historique, 2005.

ZEMELLA, Mafalda P. O Abastecimento da Capitania das Minas Gerais no Século VIII. São Paulo: Tese de Doutoramento apresentada à cadeira de História da Civilização Brasileira da Faculdade de Filosofia, Ciências e Letras da U.S.P, 1951.

\section{INTERNET}

http://comturatibaia.com.br/artigo.php?id=370. Acesso: 22 julho 2006

http://www.vidaslusofonas.pt/fernao pais leme.htm. Acesso: 22 julho 2006.

http://www.citybrazil.com.br/sp/guarulhos/historia.htm. Acesso: 22 julho 2006. 
http://www.citybrazil.com.br/sp/quarulhos/historia.htm. Acesso: 22 julho 2006.

http://www.pitoresco.com.br/historiarocha03a.htm. Acesso: 22 julho 2006.

http://www.jj.com.br/jj2opiniao/opiniao16072006-01.html. Acesso: 22 julho 2006.

http://www.multirio.rj.gov.br/historia/modulo01/setao.html.Acesso: 22 julho 2006.

http://www.atibaia.com.br/cidade/historia02.asp. Acesso: 22 julho 2006.

http://www.nazarepaulista.com.br/hist.html. Acesso: 28 agosto 2006.

http://www.diocesedebragança.org.br/historia.shtml. Acesso: 22 julho 2006.

http:/www.novomilenio.inf.br/santos/mapa41.htm. Acesso: 22 julho 2006. 


\section{ICONOGRAFIA}

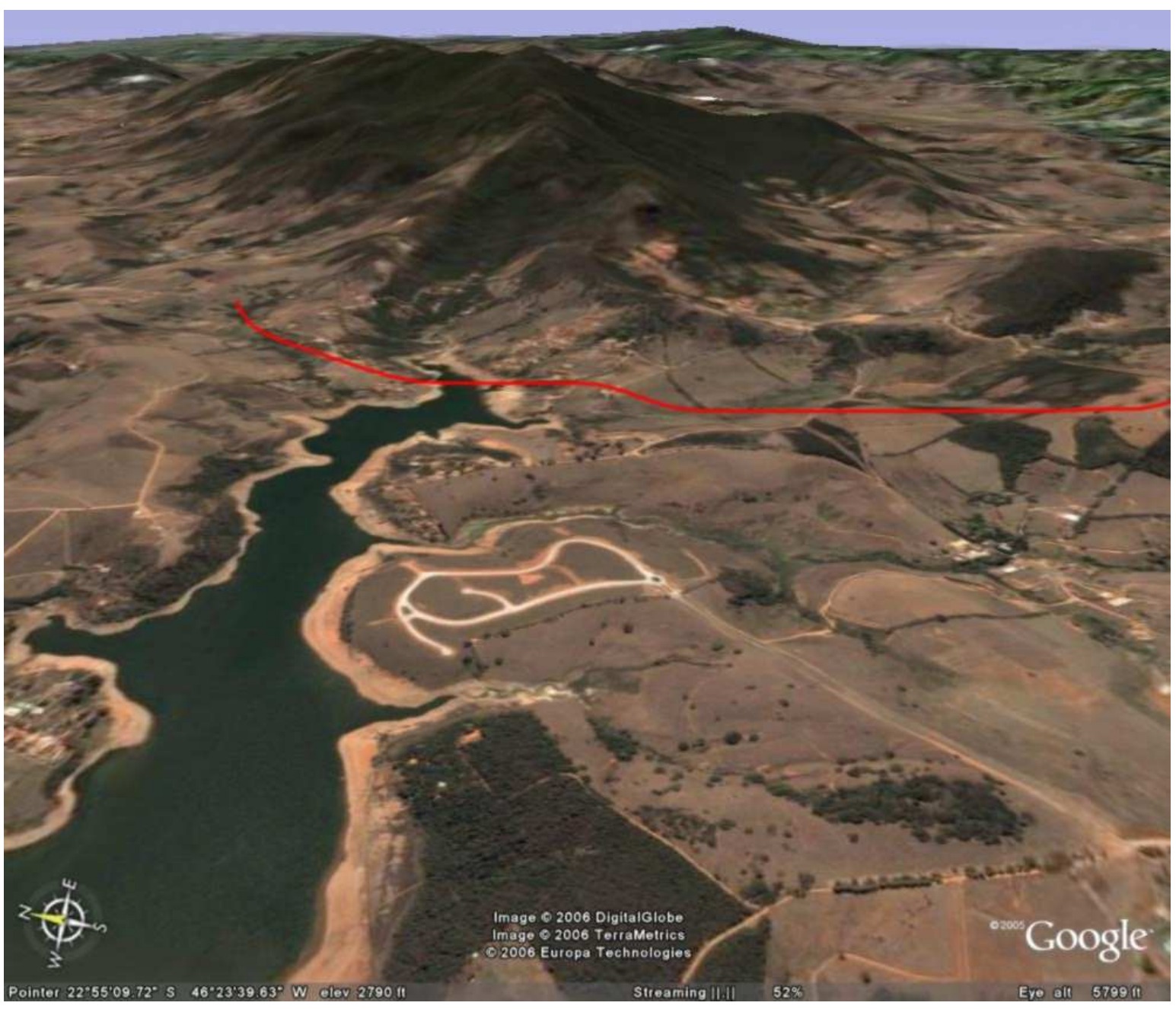

Figura 1

O vale do rio Cachoeira e o morro do Lopo.

Legenda

Caminho na garganta do rio Cachoeira tendo a direita o morro do Lopo.

Disponível em: http://earth.google.com/download-earth.html. Acesso 30 agosto 2006.

Tratamento de imagem: Ana Villanueva e Paula Takahasi. 


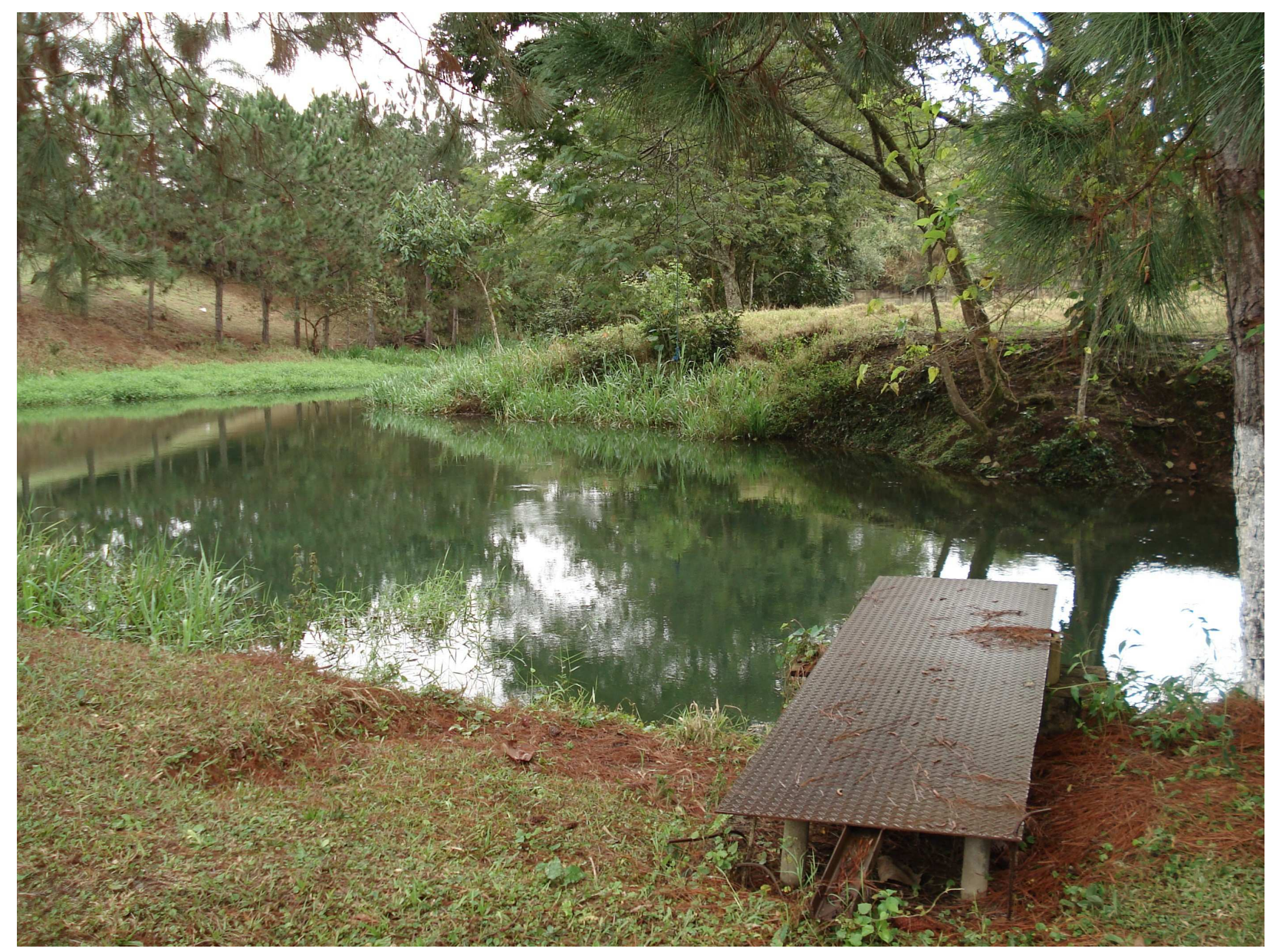

Figura 2 - Rio Cachoeira no Município de Piracaia - SP. Foto: Ismar Túlio Curi.

Data: junho 2006. 


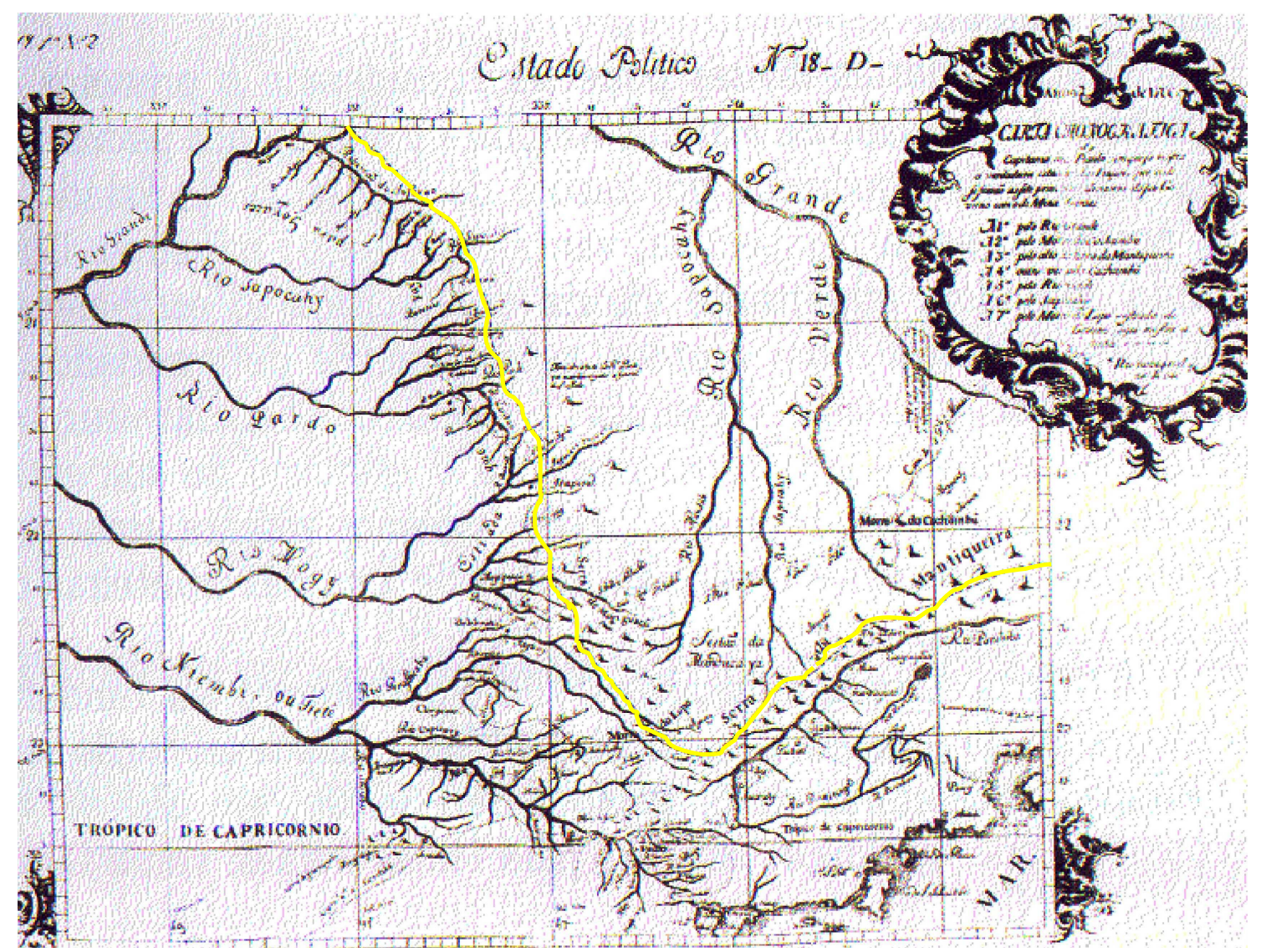

Fig. 3 - Carta Corográfica da Capitania de São Paulo, 1766, em que se mostra a verdadeira situação dos lugares por onde se fizeram as sete principais divisões do seu Governo com o de Minas Gerais: A $1^{a}$ pelo Rio Grande; A $2^{a}$ pelo Morro do Cachumbu; $A$ 3a pelo alto da Serra da Mantiqueira; $A 4^{a}$ outra vez pelo Cachumbu; A $5^{a}$ pelo Rio Verde; $A 6^{a}$ pelo Sapocahy; $A$ 7a pelo Morro do Lopo, e estrada de Goyazes, o que mostra a linha cor amarela.

Copiada pelo Major Umbelino Alberto de Campo Limpo em 1869, esta Carta Corográfica da Capitania de São Paulo, de 1766, é em tinta colorida, nanquim e aquarela, sobre papel canson com $60,5 \times 48 \mathrm{~cm}$, com nota explicativa.

Disponível em: http:/www.novomilenio.inf.br/santos/mapa41.htm. Acesso em 22 julho 2006.

Legenda

Divisão das Capitanias de São Paulo e Minas

Tratamento de imagem: Ana Villanueva. 


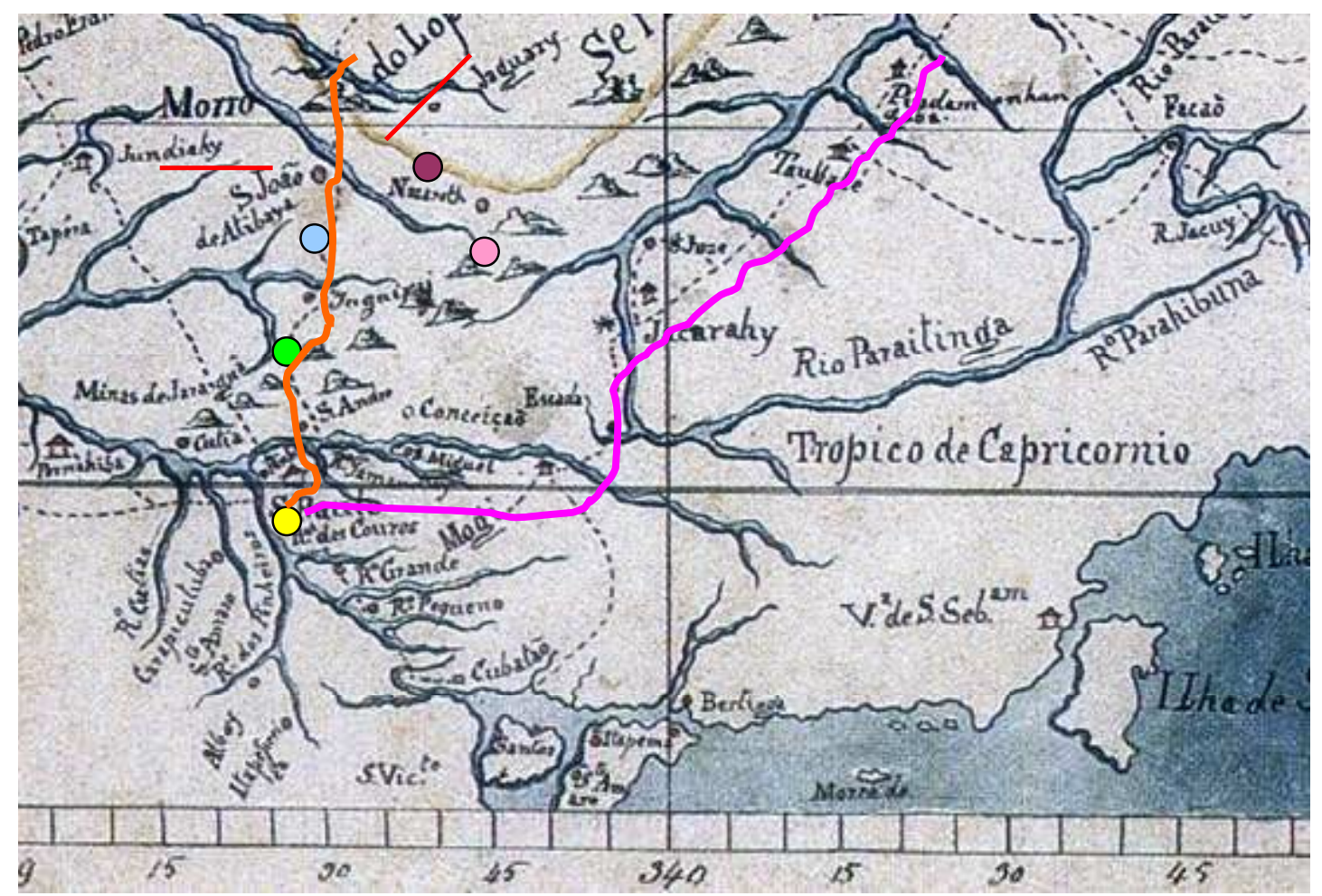

Figura 4 - Detalhe da Carta Corográfica da Capitania de São Paulo, 1766. Morro do Lopo, Caminhos e núcleos urbanos.

Reprodução-foto: Ana Villanueva.

Tratamento de imagem: Ana Villanueva e Eliane Roberto.

Data: julho 2006. julho 2006.

Disponível em: http:/www.novomilenio.inf.br/santos/mapa41.htm. Acesso em 22 Legenda

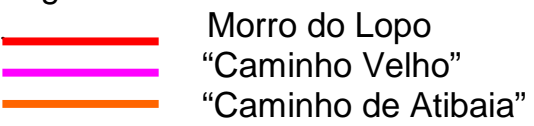

Povoados no "Caminho de Atibaia" e na região do morro do Lopo
$\bigcirc$ São Paulo
São João de Atibaia
Jaguary (Bragança)
Nazareth
Juquiry 


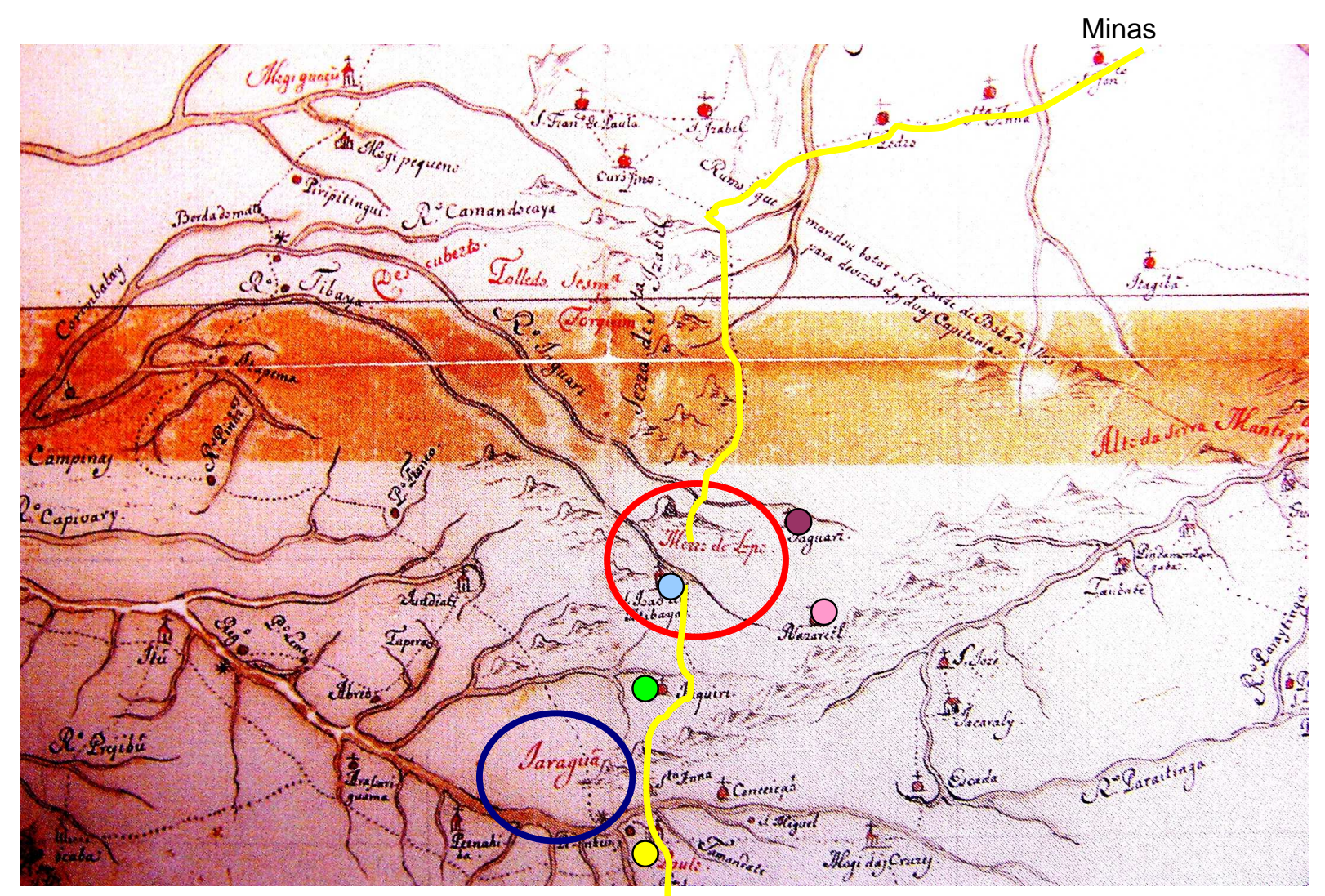

Figura 5 - Carta Chorografica para intelliga . dos pontos das devizoes $Q$ tem havido entre a Capitania de S. Paulo e a de Minas Geraes, [s.d.].

Reprodução-foto: Ana Villanueva.

Tratamento de imagem: Ana Villanueva e Eliane Roberto.

Legenda:

Caminho São Paulo - Minas, passando pelo Morro do Lopo

Morro do Lopo

Jaraguá
São Paulo
$\bigcirc$ Juquiry
São João de Atibaia
Jaguary (Bragança)
Nazareth

Data: julho 2006.

In CosTA, Antônio Gilberto (org.). Os Caminhos do Ouro e a Estrada Real. Belo Horizonte: Editora UFMG; Lisboa: Kapa Editorial, 2005. 




Figura 6 - DEMONSTRAÇÃO de P.te da Diviza desta CAPITANIA com a de S. Paulo. Ca., em 1815.

Reprodução-foto: Ana Villanueva.

Tratamento de imagem: Ana Villanueva e Eliane Roberto.

Data: julho 2006.

In COSTA, Antônio Gilberto (org.). Os Caminhos do Ouro e a Estrada Real. Belo Horizonte: Editora UFMG; Lisboa: Kapa Editorial, 2005.

Mapa DEMONSTRAÇÃO de P.te da Diviza desta CAPITANIA com a de S. Paulo. Ca., em 1815

\section{Legenda \\ Guaratinguetá \\ Morro do Lopo}


Caminho para Goiás

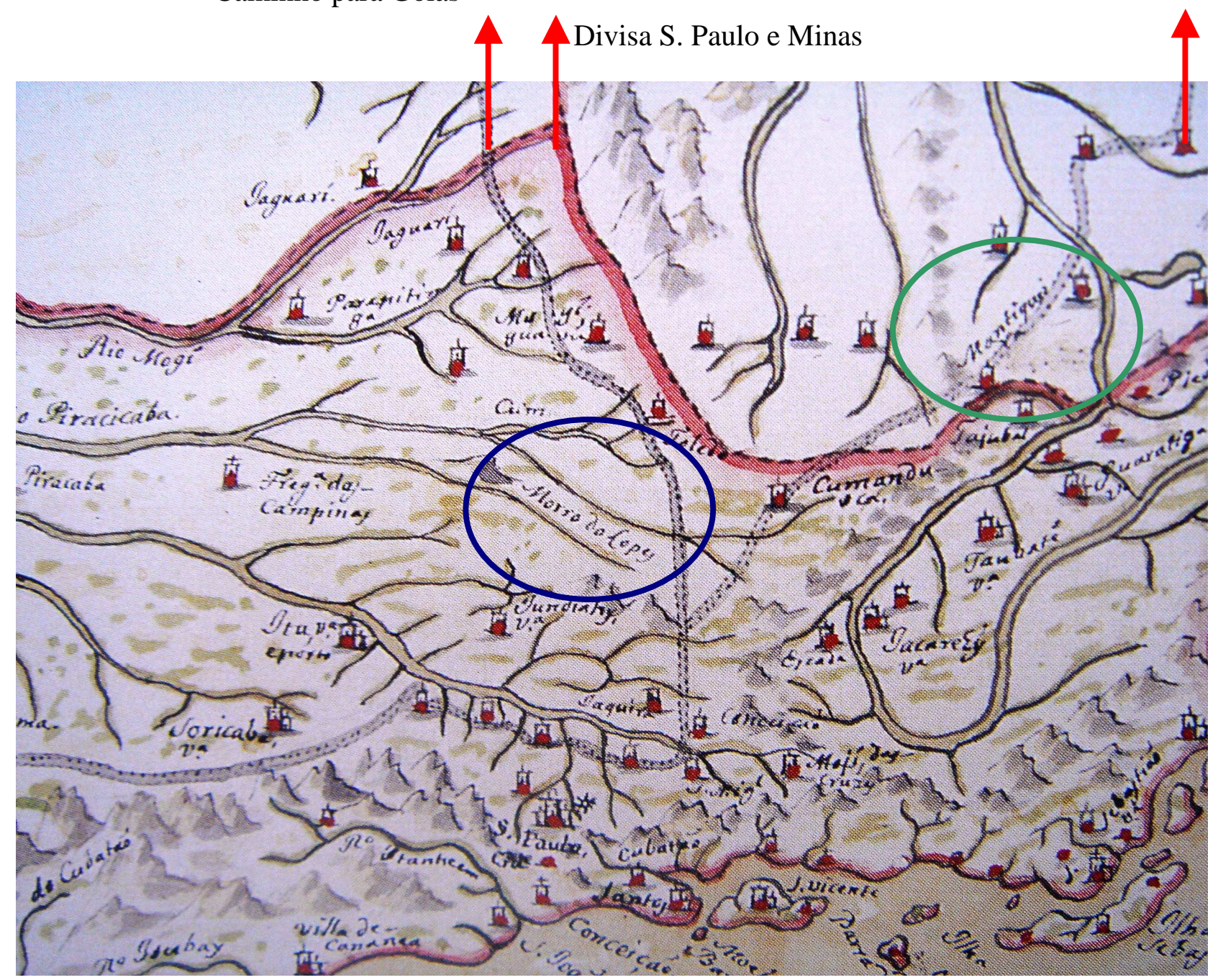

Figura 7

Legend $\bigcirc$ Morro do Lopo $\bigcirc$ Serra da Mantiqueira

Gûia de Caminhantes. Carta 4.a. Capitanîa de S. Paulo, dividida pelo circol pontedo de preto e lavado de carmizim vivo, e grosso. Onde se mostra seus mais notaveis Rios; Sítios; Povoaçoes; Capitaes; Serras; Estradas; Caminhos. Para o Senhor Capitaõ Pedro Francisco de Castro. Deliniada e Iluminada por Anastásio de S. ${ }^{\text {ta }}$ Anna. Pintor. Bahîa, e Anno. 1816.

Reprodução-foto: Ana Villanueva.

Tratamento de imagem: Ana Villanueva e Eliane Roberto.

Data: julho 2006.

In COSTA, Antônio Gilberto (org.). Os Caminhos do Ouro e a Estrada Real. Belo Horizonte: Editora UFMG; Lisboa: Kapa Editorial, 2005. 




Legenda

Garganta do Embaú - Cidade de Cruzeiro

Serra da Mantiqueira
Fig. 8 - Roteiros de entradas e bandeiras

Mapa de Minas Gerais com representação dos roteiros das principais entradas e bandeiras dos séculos XVI e XVII, no território mineiro [João C. de Oliveira Tôrres. História de Minas Gerais, p. 104a].

Reprodução-foto: Ana Villanueva.

Tratamento de imagem: Ana Villanueva e Eliane Roberto.

Data: julho 2006.

In COSTA, Antônio Gilberto (org.). Os Caminhos do Ouro e a Estrada Real. Belo Horizonte: Editora UFMG; Lisboa: Kapa Editorial, 2005. 


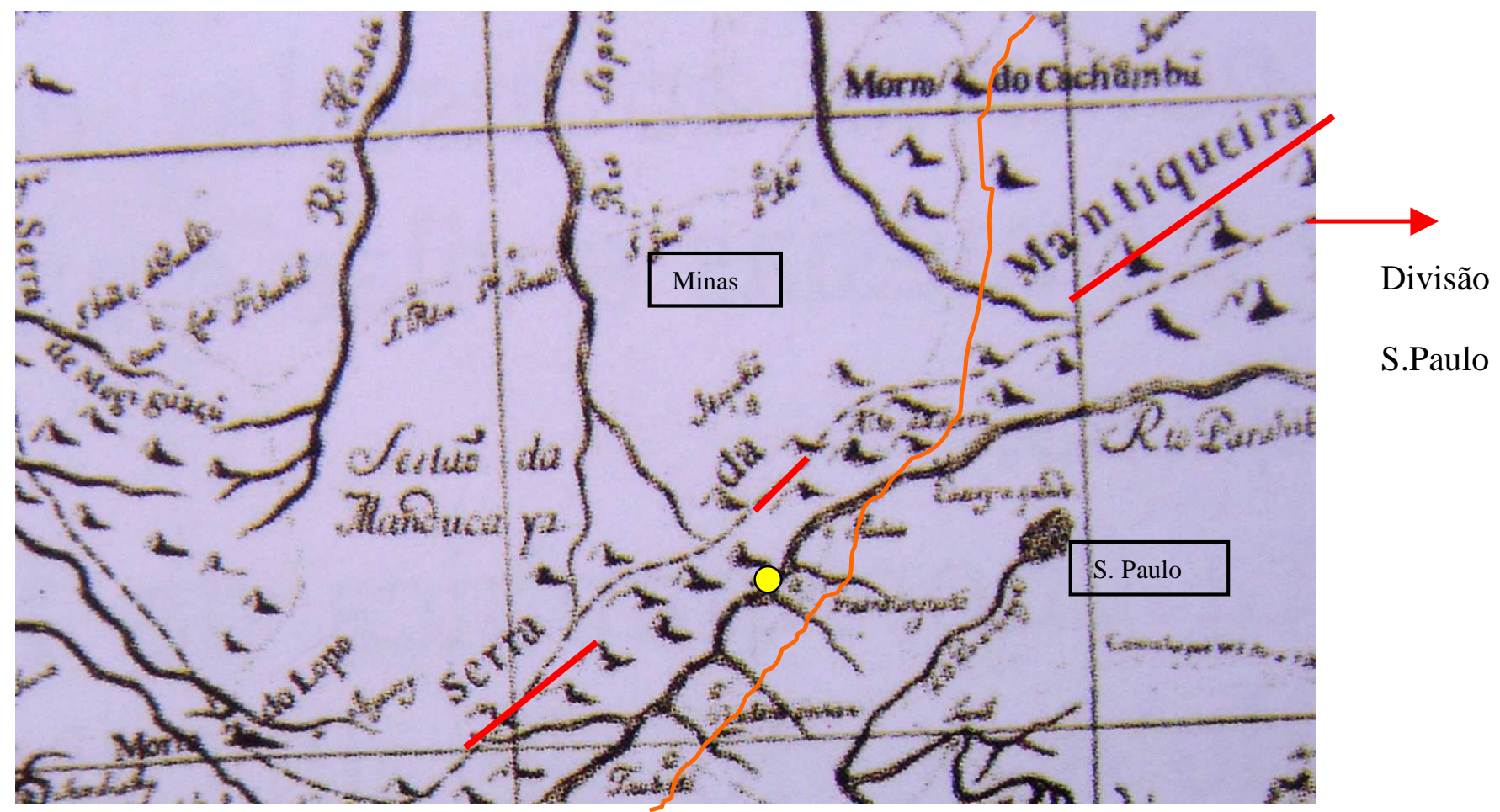

Figura 9

Detalhe da Carta Corográfica da Capitania de São Paulo, 1766.

Legenda

Caminho Velho

Serra da Mantiqueira

Detalhe da Carta Corográfica da Capitania de São Paulo, 1766. Caminho Velho e a travessia da Serra da Mantiqueira pela garganta do Embaú.

Reprodução-foto: Ana Villanueva.

Tratamento de imagem: Ana Villanueva e Eliane Roberto.

Data: julho 2006.

In SANTOS, Antonio da Costa. Campinas da Origem ao Futuro. Compra e venda de terra e água e um tombamento na primeira sesmaria da Freguesia de Nossa Senhora da Conceição das Campinas do Mato Grosso de Jundiaí (1732-1992). Campinas: Editora da UNICAMP, 2002. 


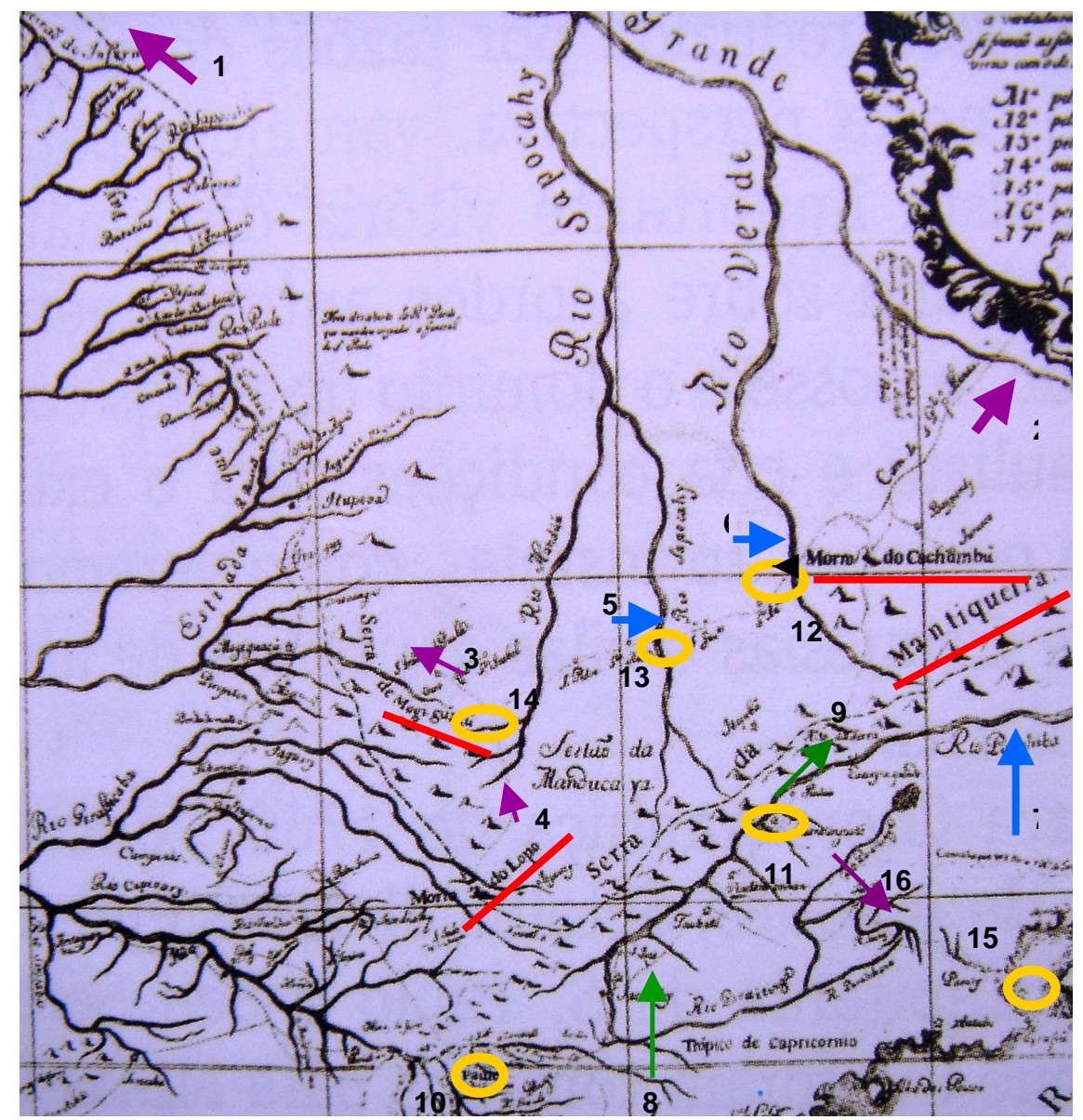

Figura 10 - Detalhe da Carta Corográfica da Capitania de São Paulo, 1766.

Legenda 1- Caminho para Goiás / 2- Caminho para Minas / 3- Caminho para Goiás / 4Caminho para Minas e Goiás via Morro do Lopo / 5- Rio Sapucay / 6- Rio Verde / 7- Rio Parahiba / 8- Caminho Velho a partir de São Paulo / 9- Caminho Velho atravessando a Serra da Mantiqueira / 10- São Paulo / 11- Guaratinguetá / 12- Encontro do Rio Verde com o Caminho / 13- Encontro do Rio Sapucay com o Caminho / 14- Bifurcação do Caminho para Goiás e Minas a partir do Caminho do Morro do Lopo / 15- Paraty / 16- Caminho para o Rio através de Paraty

Morro do Lopo, morro do Cachumbu, serra da Mantiqueira, Caminho Velho, Caminho de Atibaia, Caminho de Goais, Caminho Real para Paraty, rios Sapucay e Verde, e principais núcleos urbanos.

Reprodução-foto: Ana Villanueva.

Tratamento de imagem: Ana Villanueva e Eliane Roberto.

Data: julho 2006.

In SANTOS, Antonio da Costa. Campinas da Origem ao Futuro. Compra e venda de terra e água e um tombamento na primeira sesmaria da Freguesia de Nossa Senhora da Conceição das Campinas do Mato Grosso de Jundiaí (1732-1992). Campinas: Editora da UNICAMP, 2002. 


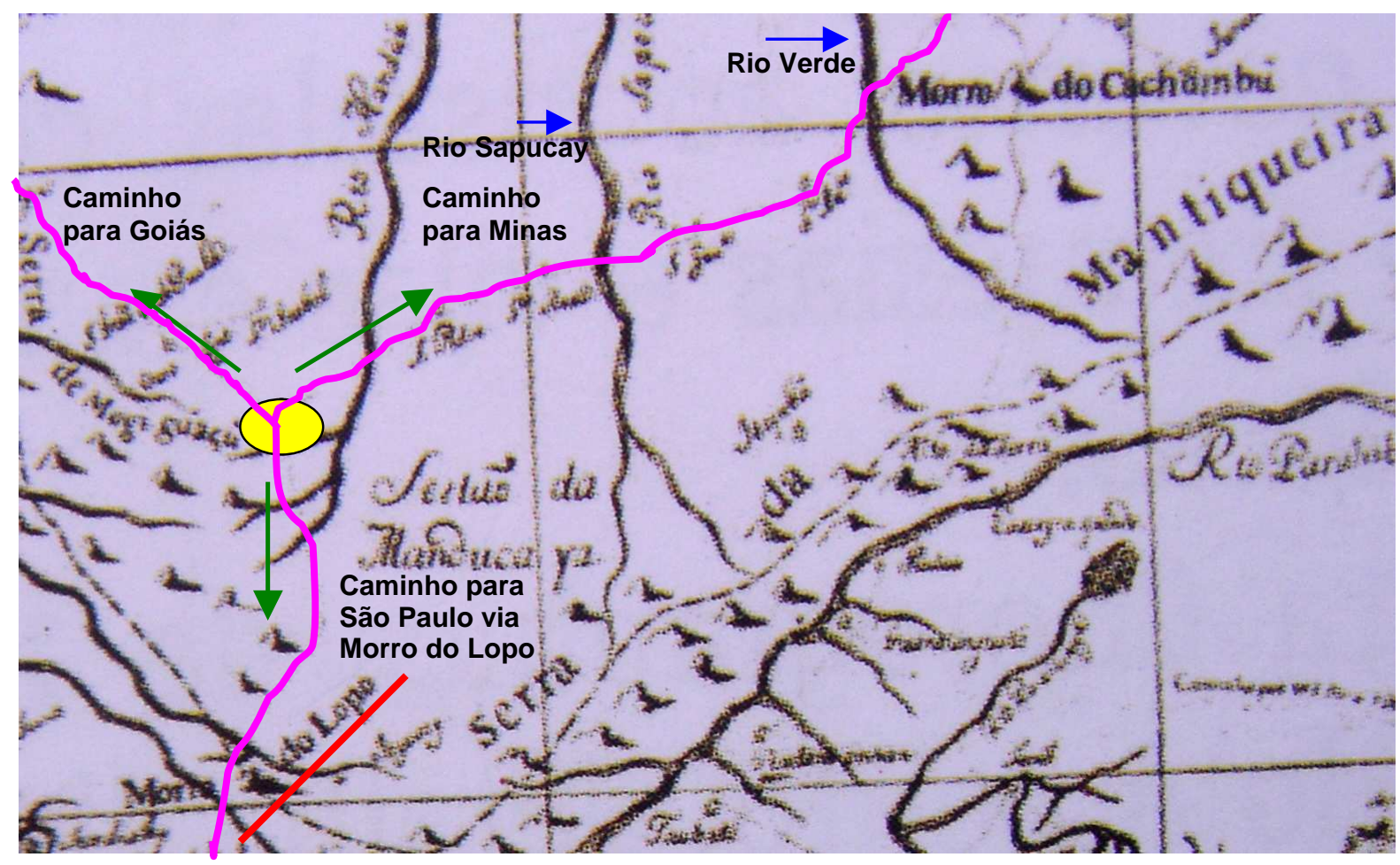

Figura 11- Detalhe da Carta Corográfica da Capitania de São Paulo, 1766.

Bifurcação ligando o Caminho de Atibaia com o Caminho de Goays, e o morro do Lopo.

Legenda

Bifurcação para o caminho de São Paulo via Morro do Lopo

Caminho para São Paulo via Morro do Lopo

Reprodução-foto: Ana Villanueva.

Tratamento de imagem: Ana Villanueva e Eliane Roberto.

Data: julho 2006.

In SANTOS, Antonio da Costa. Campinas da Origem ao Futuro. Compra e venda de terra e água e um tombamento na primeira sesmaria da Freguesia de Nossa Senhora da Conceição das Campinas do Mato Grosso de Jundiaí (1732-1992). Campinas: Editora da UNICAMP, 2002. 


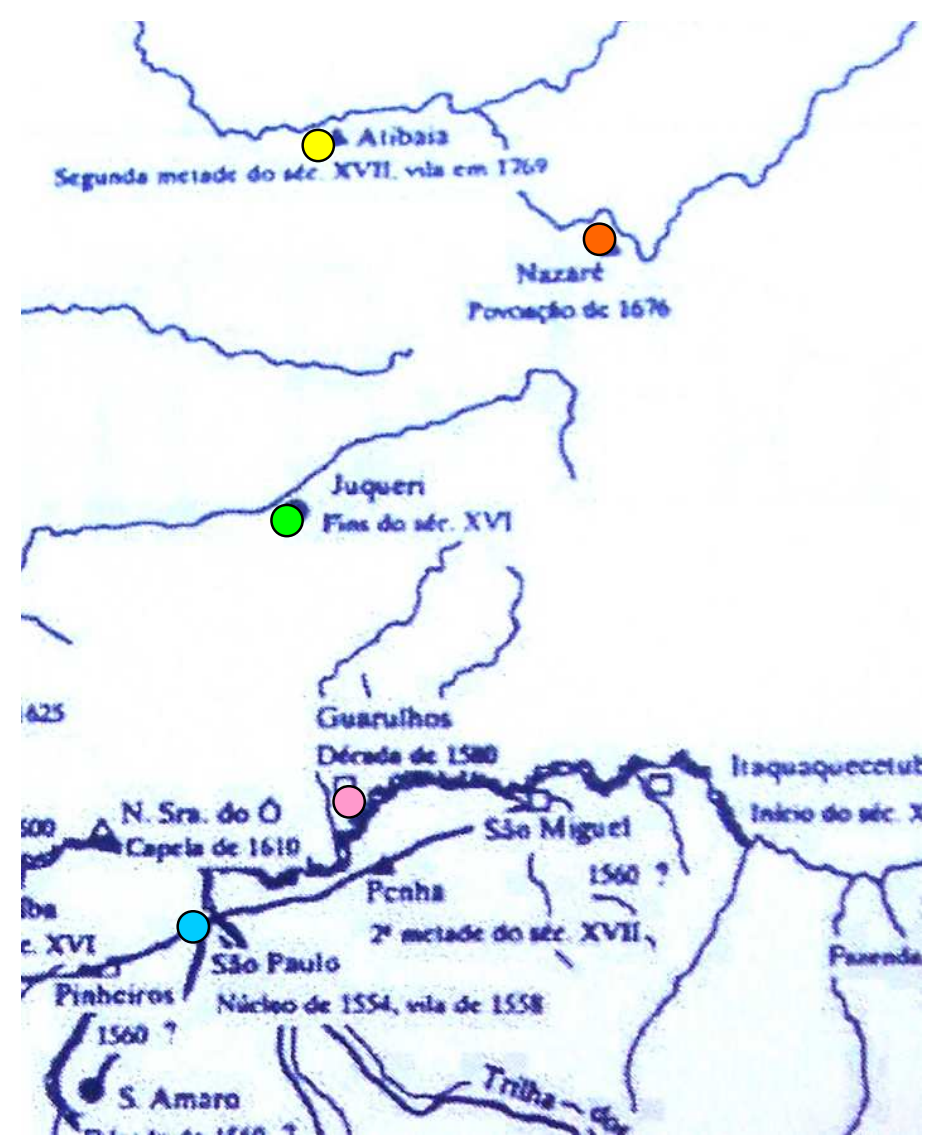

Figura 12 -Aldeamentos e Povoamentos de São Paulo até fins do século XVII Legenda

O

São Paulo

Guarulhos

$\bigcirc$ Juqueri

Nazareth

Atibaia

Reprodução-foto: Ana Villanueva.

Tratamento de imagem: Ana Villanueva e Eliane Roberto.

Data: julho 2006.

PETRONE, Pasquale. Aldeamentos Paulistas. São Paulo: Edusp, 1995. In TORRÃO FILHO. Amílcar. Paradigma do caos ou cidade da conversão ?: a cidade colonial na América Portuguesa e o caso de São Paulo na administração do Morgado de Mateus (1765-1775). Dissertação de Mestrado em História. Campinas: UNICAMP-IFCHDep. De História, 2004. 


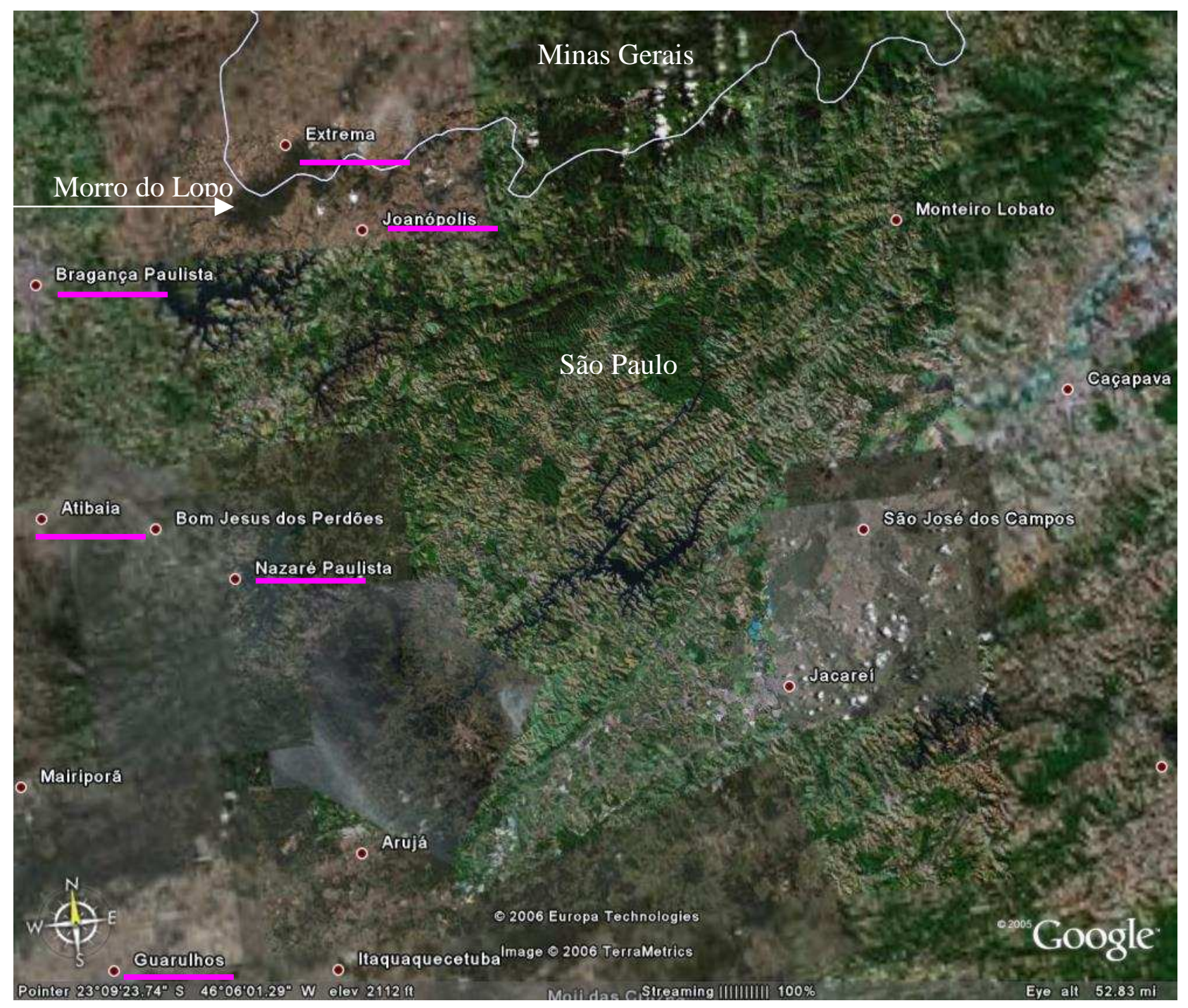

Figura 13 - Principais cidades na região do morro do Lopo.

Disponível em: http://earth.google.com/download-earth.html. Acesso 30 agosto 2006.

Tratamento de imagem: Ana Villanueva e Eliane Roberto. 
Explicacä dos Sinaes que vä̀ nestas Cartas, que se sequem, para mellor seperceber:

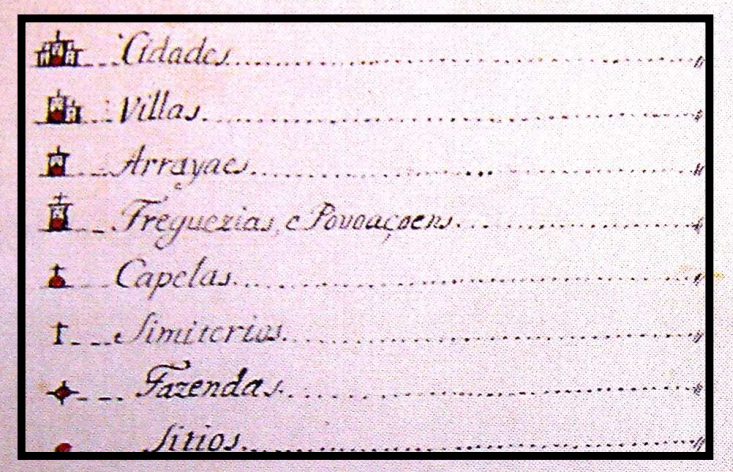

Eiradas, Reaes.

Caminhos. Rios.

Ragoas...

Partanos, ou Brejacs.

Serras.

$208 \% 9$. Mattas, ou Bosques"

Divizaó de Comarces, Capitanias, Provincias, sta

Euirimure; Anrigo nome Gentilico da Bahia, clugar onde se fundou a Cidade de S Salus dor.

Siquitaya; Praya onde foi amaior força do antigo comercio com ódudias da Ssatia.

1. 3ista da Itha de Praparica, a Merro de S. Pullo na Tha de Tintere.

Figura 14 - Detalhe da Legenda do Gûia de Caminhantes. Carta 4.a

Legenda

Situação hierárquica dos núcleos urbanos

Capitanîa de S. Paulo, dividida pelo circol pontedo de preto e lavado de carmizim vivo, e grosso. Onde se mostra seus mais notaveis Rios; Sítios; Povoaçoes; Capitaes; Serras; Estradas; Caminhos. Para o Senhor Capitaõ Pedro Francisco de Castro. Deliniada e Iluminada por Anastásio de S. ${ }^{\text {ta }}$ Anna. Pintor. Bahîa, e Anno. 1816.

Reprodução-foto: Ana Villanueva.

Tratamento de imagem: Ana Villanueva e Eliane Roberto.

Data: julho 2006.

In COSTA, Antônio Gilberto (org.). Os Caminhos do Ouro e a Estrada Real. Belo Horizonte: Editora UFMG; Lisboa: Kapa Editorial, 2005. 